\title{
DIGITAL MARKETING AS AN INTEGRATED MARKETING COMMUNICATION STRATEGY IN BADAN USAHA MILIK DESA (BUMDesa) IN EAST JAVA
}

\author{
Bambang Setiyo Pambudi, Suyono \\ Prodi S1 Manajemen, Fakultas Ekonomi, Universitas Trunojoyo
}

\begin{abstract}
The purpose of this study is how the marketing communication strategy through digital marketing is carried out by BUMDesa businesses as a driver of the village economy in order to prosper the Village Communities in East Java in marketing their products. This research is focused on the online media such as Instagram Business, Facebook Business and Whatshapp Business.

This study used qualitative research methods to provide data and facts about the application of digital marketing in Badan Usaha Milik Desa (BUMDesa). Interviews, documentation, and observation used as data collection techniques. Data is analyzed with a grounded theory approach that provides development of the field of research studies. The analysis techniques consisted of data reduction, data presentation and conclusion.

The research findings show that in marketing BUMDesa products, marketing trends are shifting from conventional (offline) to digital (online). The concept of digital marketing for BUMDesa businesses is to be able to market their products from anywhere and anytime through the internet / online media. So the communication strategy is done through digital marketing are the submission of positioning statements in each post on online media (Instagram Bisnis, Facebook Bisnis and Whatshap Bisnis) and the speed of response to online reviews of online media. Suggestions for BUMDesa in carrying out marketing activities, both conventional and especially digital marketing, can be developed for better management.

Keywords: Digital Marketing, Integrated Marketing Communication Strategy, Badan Usaha Milik Desa (BUMDesa)
\end{abstract}

\section{INTRODUCTION}

Upaya yang dilakukan oleh pemerintah Indonesia untuk mengembangkan kewirausahaan terutama bagi masyarakat di pedesaan adalah melalui pendirian Badan Usaha Milik Desa (BUMDesa) sebagai penggerak perekonomian desa. BUMDesa adalah sebuah lembaga yang berbentuk badan hukum menaungi berbagai unit usaha desa. BUMDesa diharapkan mampu menstimulasi dan menggerakkan peningkatan perekonomian di desa. BUMDesa didirikan berdasrkan pada kebutuhan dan potensi desa, sebagai upaya menaikkan kesejahteraan masyarakat. Perencanaan dan pendirian BUMDesa dibentuk atas inisiasi masyarakat, serta didasarkan prinsip-prinsip kooperatif, partisipatif, transparansi, emansipatif, akuntabel dan sustainable dengan mekanisme berbasis anggota dan pengusahaan mandiri. 
BUMDesa di Jawa Timur bertujuan diharapkan memajukan perekonomian desa, meningkatkan kesejahteraan masyarakat desa, memberikan pelayanan terhadap kebutuhan masyarakat dan pengelolaan aset-aset desa secara lebih baik. Pembentukan BUMDes diatur dalam peraturan di daerah tentang BUMDes berdasar pada UU No. 32 tahun 2004 tentang Pemerintahan Daerah Pasal 213 ayat (1) "Desa dapat mendirikan badan usaha milik desa sesuai dengan kebutuhan dan potensi desa". Rumusan yang sama diatur dalam PP No. 72 Tahun 2005 tentang Desa. Pembentukan BUMDes ditujukan untuk menggali dan mengoptimalkan potensi pengusaha desa berdasarkan UU Desa nomor 6 tahun 2014. Dalam UU Desa, Pasal 87 ayat (1) Desa dapat mendirikan Badan Usaha Milik Desa yang disebut BUMDesa; ayat (2) BUMDesa dikelola dengan semangat kekeluargaan dan kegotongroyongan; (3) BUMDesa dapat menjalankan usaha di bidang ekonomi dan/atau pelayanan umum sesuai dengan ketentuan peraturan perundang-undangan.

Pemerintah Provinsi Jawa Timur telah mengembangkan lembaga ekonomi desa (LED) dalam bentuk BUMDesa, yang sampai dengan tahun 2018 telah mencapai jumlah 3.158 BUMDesa yang tersebar di 29 Kabupaten dan 1 Kota yaitu Kota Batu. Pemetaan BUMDesa per 31 Desember 2017 di Jawa Timur telah terbentuk 3.158 BUMDesa, atau terbentuk sekitar 40,88\% dari 7.724 Desa yang terdapat di Jawa Timur. Dari maping jenis usaha 3.158 BUMDesa terdapat 4.459 jenis usaha yang terdiri dari 40,44\% usaha simpan pinjam dan 59,56\% usaha sektor riil. Pemerintah sendiri sedang mendorong BUMDesa untuk berkembang dan bisa bersaing dengan mengikuti perkembangan teknologi. Salah satu caranya dengan mengajarkan menggunakan internet yang menjadi salah satu cara untuk memudahkan pemasaran.

Era digital tidak mungkin untuk dihindari. Dengan pesatnya perkembangan teknologi, dunia digital dan internet tentu juga berimbas pada dunia pemasaran. Arah pemasaran di dunia beralih dari konvensional (offline) menjadi digital (online). Digital marketing ini lebih prospektif karena memungkinkan para calon pelanggan potensial untuk memperoleh segala macam informasi mengenai produk dan bertransaksi melalui internet. Menurut data yang dilansir oleh We are Social, sebuah agensi digital marketing di Amerika, memaparkan bahwa terhitung sampai Januari 2017, sebanyak 48\% pengguna internet di Indonesia melakukan pencarian barang atau jasa secara online, $46 \%$ pengguna mengunjungi toko online. Hal ini 
menyiratkan bahwa potensi belanja online sudah cukup berkembang di Indonesia yang harus diimbangi dengan pemasaran secara digital pula oleh para pengelola usaha. Dalam digital marketing adalah media sosial atau jejaring social merupakan platform yang sering digunakan. Data We are Social menyatakan platform media sosial paling banyak digunakan di Indonesia. Berdasarkan hasil survei yang dilakukan Indonesia digital 2019, menunjukkan bahwa media sosial yang digunakan di Indonesia adalah Facebook berada di urutan ke tiga dengan perolehan $81 \%$, dan Instagram memperoleh jumlah $80 \%$, seperti di gambar dibawah.

Gambar 1 Pengguna media sosial Indonesia Tahun 2018

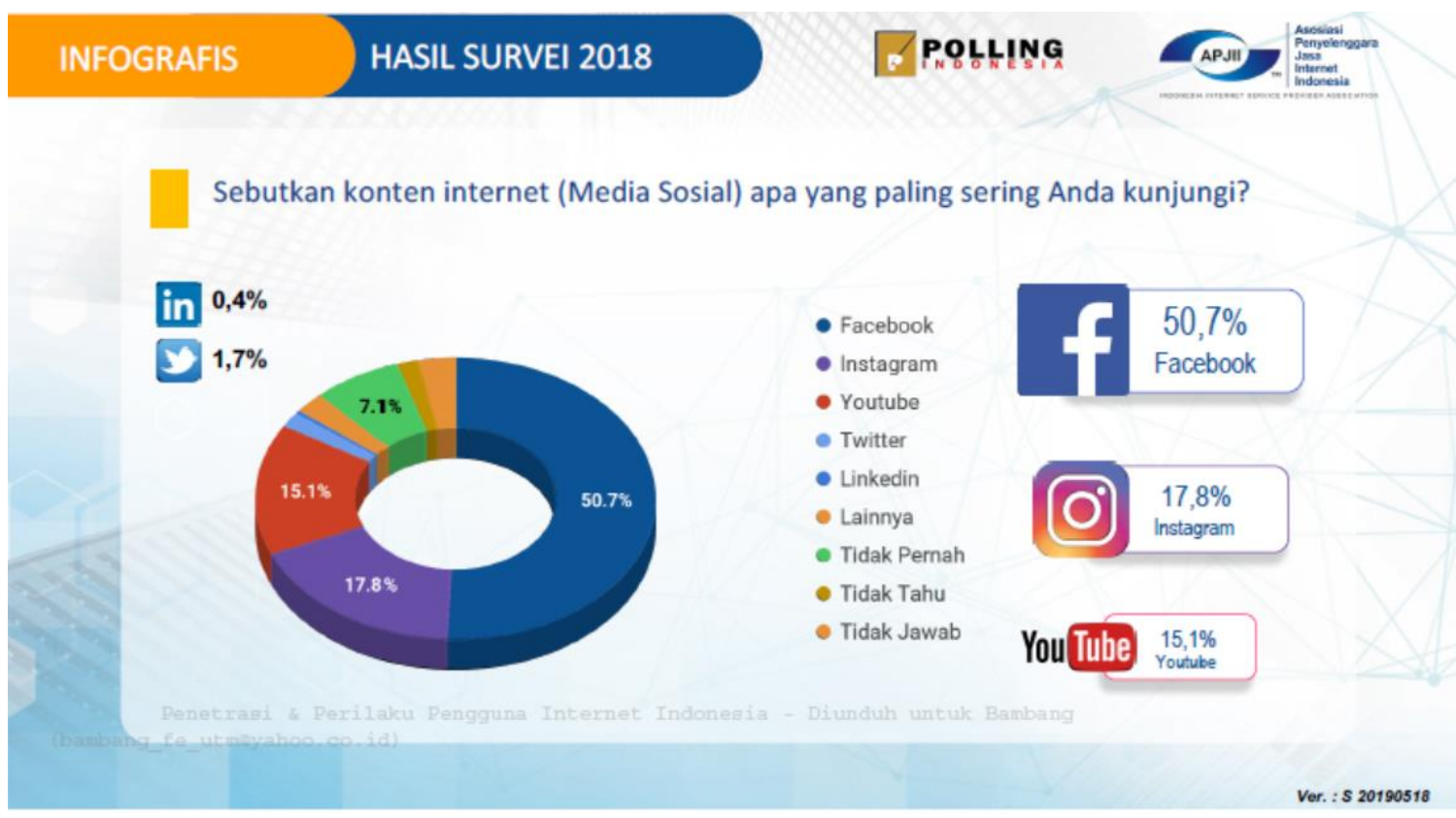

Sumber: https://websindo.com/indonesia-digital-2019-media-sosial/ 


\section{Gambar 2. Pertumbuhan Media Sosial di Indonesia}

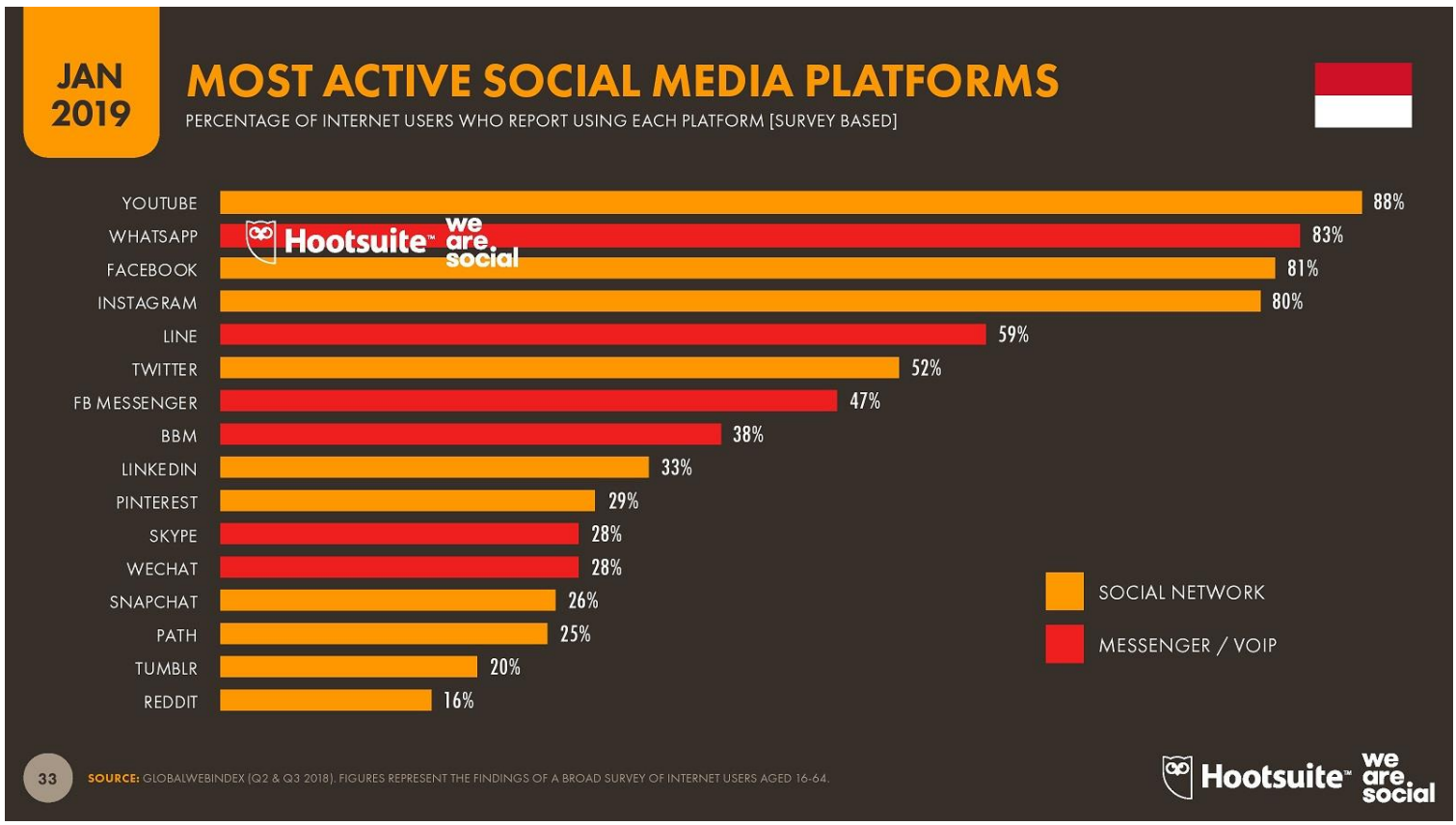

Sumber: https://websindo.com/indonesia-digital-2019-media-sosial/

We are Social juga merilis Pengguna Media Sosial Mobile : 130 juta (naik 8,3\% atau sekitar 10juta dari tahun 2018). Alat yang digunakan untuk akses internet: $60 \%$ gunakan smartphone, 22\% gunakan laptop dan komputer, $8 \%$ dari tablet. Dengan memanfaatkan internet sebagai media komunikasi dalam memasarkan produk ataupun jasa, diharapkan mampu menjangkau pasar yang lebih luas sehingga semakin banyak yang mengetahui dan dapat membeli produk atau jasa yang ditawarkan oleh BUMDesa. Gaya hidup masyarakat di Indonesia tidak bisa lepas dari gadget, generasi millenial-pun juga memanfaatkan hal tersebut, tentu ini merupakan peluang yang besar. Seiring dengan perubahan perilaku masyarakat yang lebih menaruh perhatian pada internet menjadi tantangan bagi BUMDesa dalam memasarkan produk secara online. Konsumen lebih aktif mencari menggunakan media online, karena dapat mengakses berbagai informasi lebih mudah dari sebelumnya. Adapun melalui digital marketing, semua pengelola BUMDesa melakukan promosi produk melalui digital marketing mampu mencakup kemampuan untuk melakukan banyak hal yang bisa menjangkau konsumen. Dimana pengalaman konsumen inilah yang akan mengantarkan brand maupun produk BUMDesa. Digital marketing merupakan satu upaya untuk membangun brand awareness (kesadaran merek), yang mendatangkan 
revenue (penjualan) bagi sebuah merk.

Berdasarkan data tersebut, pengelola usaha di BUMDesa bisa menentukan strategi untuk membangun komunikasi dengan konsumennya. Integrated Marketing Communication (komunikasi pemasaran terpadu), yaitu suatu konsep perencanaan komunikasi pemasaran yang mengevaluasi peran strategis dari berbagai disiplin komunikasi, misalnya periklanan umum, penjualan personal, pemasaran langsung, hubungan masyarakat, dan menggabungkan beberapa disiplin ini untuk memberikan kejelasan, konsistensi, dan pengaruh komunikasi yang maksimum melalui integrasi yang menyeluruh (Philip Kotler, 2007).

Berdasarkan latar belakang tersebut, peneliti tertarik untuk meneliti lebih lanjut tentang digital marketing dan strategi komunikasi pemasaran terpadu produk dari para pengelola BUMDesa dengan judul "Digital Marketing Sebagai Strategi Komunikasi Pemasaran Terpadu Pada Badan Usaha Milik Desa (BUMDesa) Di Jawa Timur".

\section{RUMUSAN MASALAH}

1. Bagaimana strategi komunikasi pemasaran melalui digital marketing yang dilakukan oleh pengelola Badan Usaha Milik Desa (BUMDesa) di Jawa Timur dalam memasarkan produknya?

2. Bagaimana kendala dan manfaat penerapan digital marketing bagi pengelola Badan Usaha Milik Desa (BUMDesa) di Jawa Timur?

\section{METHODS}

Penelitian ini menggunakan jenis penelitian kualitatif dengan pendekatan Grounded Theory, dengan metode Wawancara Mendalam (Indepht Interview), peneliti melakukan riset yang berfokus pada rangkaian peristiwa, tindakan, atau aktivitas individual maupun kolektif yang berkembang sesuai waktu dalam konteks tertentu. Grounded theory digunakan untuk kondisi ketika sedikit sekali informasi yang diketahui dari topik atau sebuah fenomena tertentu. Tujuan grounded theory adalah membangun sebuah teori baru, meskipun sering digunakan dalam memperluas atau memodifikasi teori yang sudah Obyek yang akan dikaji dalam penelitian ada (Strauss, et.all, 1998). 
Pendekatan dalam penelitian ini tidak memulai penyelidikan dengan satu teori tertentu lalu membuktikannya, namun dengan suatu bidang kajian dan hal-hal yang terkait dengan bidang tersebut. Metode grounded theory ini adalah bagaimana menyusun teori dan menjelaskan bidang yang diteliti. Perumusan masalah dalam grounded theory cenderung berorientasi pada proses dan tindakan (Tri Nugroho Adi, 2007). Menurut peneliti yang sesuai untuk menggali informasi mengenai penerapan digital marketing dan strategi komunikasi pemasaran terpadu dari Usaha BUMDesa yaitu dengan menggunakan pendekatan grounded theory. Dengan Tahapan analisis data menggunakan model Miles dan Huberman. Adapun tahapan analisis data dalam model ini yaitu (Sugiyono, 2011).

\section{OBYEK PENELITIAN}

Obyek yang dikaji dalam penelitian ini adalah digital marketing sebagai strategi komunikasi pemasaran terpadu. Sasaran obyek peneliti ini mengenai strategi komunikasi pemasaran terpadu, tetapi lebih mengacu ke pembahasan penerapan digital marketing pada badan Usaha BUMDesa.

\section{LOKASI PENELITIAN}

1. BUMDesa dengan lokasi di wilayah Kota Bondowoso yang meliputi beberapa BUMDesa,

2. BUMDesa dengan lokasi di wilayah Kota Malang

\section{JENIS DAN SUMBER DATA}

Menurut Lofland (Lexy J. Moleong, 2009), sumber utama data dalam penelitian kualitatif adalah perkataan dan tindakan, selebihnya adalah data tambahan seperti dokumen dan lain-lain. Berbagai jenis datanya dibagi kedalam kata- kata dan tindakan, sumber data tertulis, photo dan statistik. Sumber dan Jenis data yang digunakan dalam peneliti adalah :

\section{Data Primer}

Data primer peneliti diperoleh dari data secara langsung dari informan yang terpilih pada lokasi penelitian. Data primer diperoleh melalui wawancara dengan 
informan. Data primer ini merupakan data yang diperoleh peneliti dari hasil wawancara dengan pengurus dan pengelola BUMDesa. Berikut data informan yang akan dikaji dalam penelitian ini:

- Pak Sucipno, 35 tahun (BUMDesa "Makmur Sejahtera", desa Sukosari Kidul, Kecamatan Sukosari, Kabupaten Bondowoso).

- Pak Yani (Ketua BUMDesa Sumber Agung, Desa Alas Sumur, Kecamatan Pujer Kabupaten Bondowoso),

- Pak Saleh M, MPd yang merupakan ketua BUMDesa Rejoagung Makmur di desa Rejoagung Kecamatan Sumber Wringin

- Pak Agus (Ketua BUMDesa Bersama) Kecamatan Singosari Kab.Malang

- Kepala desa serta sekdes, BUMDesa Maju Bersama di desa Tunjung Tirto Kecamatan Singosari Kab Malang

\section{Data Sekunder}

Peneliti akan memperoleh data melalui studi dokumentasi dengan mempelajari berbagai tulisan seperti buku, jurnal, skripsi dan internet untuk mendukung penelitian ini.

\section{LITERATURE REVIEW}

\section{Strategi Komunikasi Pemasaran Terpadu}

Awal 1990-an, Pakar pemasaran dan profesional mulai memunculkan istilah komunikasi pemasaran terpadu (IMC) (Schultz, 1991; Moore dan Thorson, 1996). Secara keseluruhan, IMC memainkan peran penting dalam strategi pemasaran, terutama dalam hal branding / merk (terutama dalam strategi pemasaran). Definisi ini menekankan proses komunikasi pemasaran terpadu yang memanfaatkan semua bentuk promosi untuk menciptakan hasil yang maksimum. Sementara itu, Philip Kotler mengartikan IMC sebagai konsep di mana suatu perusahaan secara hati-hati mengintegrasikan dan mengkoordinasikan saluran komunikasinya yang banyak untuk menyampaikan pesan yang jelas, konsisten, dan meyakinkan mengenai perusahaan dan produknya. (Kotler, 1997) 
Strategi merupakan cara cermat dan sistematis mengenai suatu kegiatan untuk mencapai sasaran khusus. Menurut Morissan, dalam merancang strategi komunikasi pemasaran terpadu, perusahaan harus mengkombinasikan berbagai elemen yang terdapat dalam bauran promosi atau promotional mix dengan memperhitungkan kekuatan dan kelemahan dari masing-masing elemen tersebut.

Dalam pemasaran, Kotler dan Amstrong menjelaskan bahwa strategi komunikasi pemasaran terbagi dalam tiga aktivitas utama yaitu perencanaan, pelaksanaan, dan evaluasi program komunikasi pemasaran terpadu (Philip Kotler \& Gary Amstrong, 1997).

Sehingga dapat dikatakan bahwa strategi komunikasi pemasaran terpadu yang dimaksud adalah rencana dalam melakukan segala aktivitas pemasaran dengan menggabungkan semua elemen bauran pemasaran (marketing mix) untuk mencapai suatu tujuan dalam perusahaan.

Elemen-elemen dari komunikasi pemasaran terpadu yang terdiri dari, iklan, penjualan personal, promosi penjualan, hubungan masyarakat dan publisitas, pemasaran langsung, dan pemasaran interaktif/internet (Morissan).

a.) Periklanan (advertising) adalah semua bentuk penyajian dan promosi nonpersonal atas ide, barang atau jasa yang dilakukan oleh perusahaan tertentu. Tujuan utama Periklanan yaitu harus menggugah perhatian calon konsumen untuk tertarik dan membeli produk atau jasa yang ditawarkan perusahaan.

b.) Penjualan personal (personal selling) adalah komunikasi langsung (tatap muka) antara penjual dan calon pembelinya (person-to-person communication) dimana pihak perusahaan dapat berinteraksi langsung dengan konsumen.

c.) Promosi penjualan (sales promotion) adalah istilah kegiatan pemasaran yang memberikan nilai tambah atau insentif kepada tenaga penjualan, distributor, atau konsumen yang diharapkan dapat meningkatkan penjualan.

d.) Hubungan masyarakat dan publisitas. Adalah sebuah upaya komunikasi yang menyeluruh dari suatu perusahaan untuk mempengaruhi persepsi, opini, keyakinan, dan sikap berbagai kelompok terhadap perusahaan tersebut.

e.) Pemasaran langsung (direct marketing) adalah upaya dari perusahaan berkomunikasi secara langsung dengan calon pelanggan sasaran bermaksud untuk mendapatkan tanggapan dan/atau transaksi penjualan. 
f.) Pemasaran interaktif / internet. Dikenal dengan istilah web marketing, online marketing, e-marketing, atau e-commerce.

g.) internet marketing diartikan pemasaran dengan menggunakan teknologi internet sebagai saluran penyampaian pesan kepada banyak orang secara bersamaan dan seketika dalam waktu tertentu.

\section{Badan Usaha Milik Desa (BUM Des)}

BUMDesa sebagai bentuk lembaga usaha desa dikelola oleh masyarakat dan pemerintahan desa sebagai upaya memperkuat dan meningkatkan perekonomian desa dan dibentuk berdasarkan kebutuhan dan potensi desa (Alkadafi, 2014). BUMDesa adalah cerminan bentuk kemandirian suatu Desa sebagai implementasi otonomi Desa. Dengan BUMDesa, diharapkan Desa tidak sepenuhnya bergantung pada subsidi dari pemerintah. BUMDesa dapat dijadikan suatu alternatif lain yang memberikan tambahan terhadap keuangan Desa (Risadi, 2012). BUMDesa dapat digunakan sebagai cara untuk mengelola aset dan kekayaan Desa agar dapat digunakan sebesar-besarnya untuk kesejahteraan masyarakat Desa.

BUMDesa adalah salah satu pilar kegiatan ekonomi di desa yang berfungsi sebagai lembaga sosial dan komersial. BUMDesa juga merupakan lembaga sosial untuk kepentingan masyarakat melalui kontribusi dalam penyediaan pelayanan sosial. Juga sebagai lembaga komersial bertujuan untuk mencari keuntungan melalui penawaran sumberdaya lokal (barang dan jasa). Prinsip efisiensi dan efektifitas juga harus dijalankan. Sebagai ban hukum, BUMDesa dibentuk berdasarkan perundang-undangan dan sesuai kesepakatan di masyarakat desa. Dengan demikian, bentuk BUMDesa dapat beragam di setiap desa di Indonesia. Berbagai macam bentuk disesuaikan dengan karakteristik lokal, potensi, dan sumberdaya yang dimiliki desa. Pengaturan lebih lanjut tentang BUMDesa diatur melalui Peraturan Daerah (PKDSP, 2007).

Desa perlu mendirikan lembaga yang menggunakan seluruh potensi dan kearifan lokal desa. Dijadikan wadah bagi setiap warga Desa untuk memberikan kontribusi pada desa. Lembaga yang sesuai bagi masyarakat desa adalah BUMDesa. BUMDesa dengan semangat gotong royong harus bertujuan untuk memberikan keadilan sosial dan kesejahteraan masyarakat Desa (Bratha, 1968). 
Pendirian BUMDesa dilandasi oleh UU No. 32 tahun 2004 tentang Pemerintahan Daerah dan PP No. 72 Tahun 2005 tentang Desa. Secara rinci tentang kedua landasan hukum BUMDesa adalah:

a. UU No. 32 tahun 2004 tentang Pemerintahan Daerah; Pasal 213 ayat (1) "Desa dapat mendirikan badan usaha milik desa sesuai dengan kebutuhan dan potensi desa".

b. PP No. 72 Tahun 2005 tentang Desa; Pasal 78, Pasal 79 Pasal 80 dan Pasal 81.

\section{Digital Marketing}

Menurut Dave Chaffey, digital marketing merupakan atau pemasaran digital memiliki arti yang hampir sama dengan pemasaran elektronik (e-marketing) keduanya menggambarkan manajemen dan pelaksanaan pemasaran menggunakan media elektronik, jadi yang dimaksud digital marketing adalah penerapan teknologi digital yang membentuk saluran online (channel online) ke pasar (website, e-mail, database, digital TV dan melalui berbagai inovasi terbaru lainnya termasuk di dalamnya blog, feed, podcast, dan jejaring sosial) yang memberikan kontribusi terhadap kegiatan pemasaran yang bertujan untuk mendapat keuntungan serta membangun dan mengembangkan hubungan dengan pelanggan selain itu mengembangkan pendekatan yang terencana untuk meningkatkan pengetahuan tentang konsumen (terhadap perusahaan, perilaku, nilai dan tingkat loyalitas terhadap merek produknya), kemudian menyatukan komunikasi yang ditargetkan dengan pelayanan online sesuai kebutuhan masing-masing individu atau pelanggan yang spesifik. Digital marketing adalah melalui penerapan teknologi dan media digital, khususnya internet untuk mencapai tujuan pemasaran. (Chafey, Dave et al, 2000)

Digital marketing adalah penerapan teknologi digital yang membentuk saluran online (channel online) ke pasar (website, e-mail, database, digital TV dan melalui berbagai inovasi terbaru lainnya termasuk di dalamnya blog, feed, podcast, dan jejaring sosial) yang memberikan kontribusi terhadap kegiatan pemasaran yang bertujan untuk mendapat keuntungan serta membangun dan mengembangkan hubungan dengan pelanggan selain itu mengembangkan pendekatan yang terencana untuk meningkatkan pengetahuan tentang konsumen (terhadap perusahaan, perilaku, nilai dan tingkat 
loyalitas terhadap merek produknya), kemudian menyatukan komunikasi yang ditargetkan dengan pelayanan online sesuai kebutuhan masing-masing individu atau pelanggan yang spesifik. Digital marketing adalah tercapainya tujuan pemasaran melalui penerapan teknologi dan media digital.

\section{Media Digital}

Adapun banyak teknik komunikasi online yang harus ditinjau oleh pemasar sebagai bagian dari strategi komunikasi bisnis digital atau sebagai bagian dari perencanaan kampanye pemasaran online suatu perusahaan. Saluran media digital (digital media channels) adalah teknik komunikasi online yang digunakan untuk mencapai tujuan kesadaran merek, keakraban, kesenangan, dan untuk memengaruhi niat membeli dengan mendorong pengguna media digital untuk mengunjungi situs web untuk terlibat dengan merek atau produk dan pada akhirnya untuk membeli secara online atau offline melalui saluran media seperti melalui telepon atau di dalam toko.

Media sosial (Social Media) adalah media yang didesain untuk memudahkan interaksi sosial yang bersifat interaktif dan dua arah. Media sosial berbasis pada teknologi internet dengan pola penyebaran informasi bersifat dari satu ke banyak audiens, berubah banyak audiens ke banyak audiens.

Media sosial merupakan sekelompol aplikasi yang berbasiskan pada internet dan dibangun berdasarkan kerangka pikiran ideologi dan teknologi dari platform Web 2.0, medium ini dapat menghubungkan individu dengan individu untuk sharing dan berkumpul secara online (Andreas Kaplan and Michael Haenlein, 2010). Web 2.0 merupakan suatu platform dasar terbentuknya media sosial, platform ini menyediakan kemudahan bagi penggunanya untuk berkolaborasi secara online dan berbagi (sharing). Media sosial seperti Facebook, Twitter, Youtube, Instagram, saat ini digunakan untuk menyebarluaskan informasi secara cepat, viral, dan menyebar kepada pengguna internet dalam jumlah yang besar.

\section{Karakteristik Media Sosial}

Dalam jurnal User Participation of Social Media, disebutkan lima karakteristik utama dalam media sosial: 
a. Participation, adalah tindakan berorientasi pada keterlibatan pengguna dalam menggunakan media sosial, berupa frekuensi kunjungan dan lama penggunaan.

b. Openes, sebuah kondisi saat media sosial mengakses informasi dan membagikan konten tertentu dengan tanpa hambatan.

c. Conversation, merupakan penyebaran percakapan secara cepat karena kemudahan akses dengan internet yang terjadi di media sosial.

d. Community, yaitu sebuah mekanisme option bagi individu atau organisasi untuk membentuk komunitas yang memiliki kesamaan minat yang dibentuk dalam media sosial.

e. Conectedness, informasi dalam media sosial berkarakteristik viral, kondisi ini memberikan kemudahan bagi penggunanya untuk terhubung satu dengan yang lain.

Teknologi digital akan membantu manajemen perusahaan sehingga aktivitas pemasaran akan mengarah pada dua hal, yakni peningkatan pendapatan dan pengurangan biaya yang akhirnya secara efektif meningkatkan nilai perusahaan. Konsumen dapat mereduksi waktu yang mungkin digunakan hanya untuk melihat produk secara langsung, media sosial berfungsi untuk menampilkan produk setiap waktu.

\section{Facebook Bisnis}

Selain akun personal atau profile, Facebook juga mengeluarkan Fan Page Facebook atau Halaman Facebook seperti blog yang menyediakan informasi yang beragam sesuai dengan keinginan pemiliknya, mulai dari perusahaan, pendidikan, layanan, produk fisik, artis, komunitas, dan masih banyak lainnya. Fitur ini lebih mengarah ke bidang bisnis. Tujuannya untuk memberikan info terbuka kepada publik, selain itu Facebook juga menyediakan segala kebutuhan untuk beriklan menggunakan Facebook Ads. Dengan adanya Fan Page membuka kesempatan pemilik halaman terhubung dengan lebih banyak pelanggan dan bisa untuk bergabung membuat sebuah komunitas dan mengembangkannya. Sedangkan Facebook Ads (Iklan Facebook), membantu pemilik halaman untuk menemukan orang yang tepat (target), menarik perhatian mereka, dan mendapatkan hasil. Dua miliar pengguna Facebook setiap bulan, menjadikan Facebook aplikasi yang potensial. Fitur Facebook for Business semakin lengkap dengan aplikasi WhatsApp Business yang memudahkan pemilik halaman dapat 
berinteraksi dengan pelanggan secara mudah dengan menggunakan alat untuk mengotomatiskan, mengurutkan, dan dengan cepat menanggapi pesan.

\section{Instagram}

Instagram adalah aplikasiyang digunakan untuk membagikan video dan photo. Instagram sendiri merupakan bagian dari Facebook, setelah Mark Zuckenberg mengakuisisinya pada tahun 2012. Dan karena merupakan bagian dari Facebook, memungkinkan teman di Facebook bisa mem-follow akun instagram kita. Makin populernya Instagram sebagai aplikasi yang digunakan untuk membagi photo, membuat banyak penggunanya yang mulai melakukan bisnis online dengan mempromosikan produk-produknya melalui Instagram. Instagram menjadi media sosial yang banyak peluang untuk berbisnis bagi para penggunanya, dimanfaatkan sebagai media komunikasi pemasaran, melalui share photo-photo produk, dan memiliki banyak followers, Atmoko, 2012. Instagram memberikan kemudahan konsumen melihat produk yang dijual dan langsung memberi komentar pada photo yang diminati.

Fitur tambahan yakni Instagram Stories. Fitur untuk pengguna untuk membuat dan membagi konten lebih banyak yang tidak akan muncul di profile grid atau dalam Instagram feed. Memungkinkan pengguna untuk mengirimkan video dan photo yang menghilang setelah 24 jam. Fitur juga dapat digunakan untuk pengembangan brand dengan membagi konten dibalik layar (behind-the-scenes). Dengan Instagram stories, memiliki peluang bagi brand untuk membawa followers ke dalam sebuah cerita kisah dibalik postingan feed stories mereka.

\section{Instagram for Business (Instagram untuk Bisnis)}

Dikutip dari situs business.instagram.com, di tahun 2016 diluncurkan fitur bisnis Instagram baru untuk membantu perusahaan memahami follower lebih baik dalam mengembangkan bisnisnya. Dengan fitur baru tersebut, pelanggan dapat melihat informasi penting di profil akun Instagram sebuah perusahaan seperti alamat bisnis atau info kontak dari akun perusahaan. Dan dapat memperoleh informasi yang dapat ditindak lanjuti tentang kiriman yang memiliki kinerja terbaik, hari dan waktu terbaik untuk mengirim, serta perincian demografi pengikut akun perusahaan tersebut. Bisa juga untuk mempromosikan kiriman yang sudah pernah dibagikan, dan menyertakan tombol 
seperti "Pelajari Selengkapnya", untuk menjangkau pelanggan baru di pemirsa target dari perusahaan.

\section{Pemanfaatan Digital Marketing oleh Pelaku Usaha}

Menurut Stelzner, media sosial berpotensi untuk membantu pelaku Usaha dalam memasarkan produknya. Aplikasi media sosial tersedia mulai dari pesan instan hingga situs jejaring sosial yang menawarkan pengguna untuk berinteraksi, berhubungan, dan berkomunikasi satu sama lain (Dedi Purwana ES, dkk, 2017). Aplikasi-aplikasi ini bermaksud untuk menginisiasi dan mengedarkan informasi online tentang pengalaman pengguna dalam mengonsumsi produk atau merek, dengan tujuan utama meraih engage atau mengikutsertakan masyarakat. People engagement dapat mengarah kepada penciptaan profit.

Stockdale, Ahmed, dan Scheepers berhasil mengidentifikasi business value dari penggunaan media sosial bagi Usaha Kecil (Dedi Purwana ES, dkk, 2017) adalah sebagai berikut: 1.) Terciptanya saluran pemasaran yang berkelanjutan; 2.) Peningkatan pendapatan jangka pendek dan penjualan jangka panjang; 3.) Penurunan biaya advertising hingga 70\%; 4.) Reduksi dalam biaya pemasaran secara keseluruhan; 5.) Terciptanya competitive advantage; 6.) Kemudahan promosi lintas platform media sosial; 7.) Peningkatan popularitas merek dan produk; 8.) Pengenalan organisasi atau perusahaan ke masyarakat.

Sosialisasi dalam strategi digital marketing sebagai bentuk pemanfaatan media sosial sangatlah penting karena dapat memberi pengetahuan kepada para pelaku UMKM mengenai cara maupun tahapan dalam memperluas jaringan konsumen melalui pemanfaatan media sosial dalam memasarkan produknya sehingga dapat meningkatkan keunggulan bersaing bagi UMKM itu sendiri.

\section{KAJIAN TEORI}

Teori Komunikasi Pemasaran Terpadu Integrated Marketing Communication (IMC) -Konsep Dasar IMC (Integrated Marketing Communication)

Integrated Marketing: Marketers Convinced Its Time Has Arrived yang dikutip tahun 1980-an, berbagai perusahaan di negara-negara maju, khususnya Amerika Serikat, 
melakukan integrasi promosi untuk meningkatkan penjualan. Komunikasi pemasaran terpadu atau integrated marketing communications (IMC), mencakup koordinasi berbagai elemen promosi dan kegiatan pemasaran lainnya (Morissan. 2015).

Tokoh pencipta IMC, Don Schultz, pun menjelaskan bahwa integrasi sangat masuk akal bagi mereka yang merencanakan sukses di pasar abad 21, pemasar, komunikator, dan perusahaan-perusahaan yang memiliki merek tidak lagi mempunyai pilihan lain (Shimp, Terence A. 2003). Penggunaan IMC mengharuskan terjadi perubahan fundamental dalam komunikasi pemasaran tradisional; yaitu memandang dan memisahkan elemen pemasaran (iklan, promosi, penjualan, hubungan masyarakat) seharusnya bisa diintegrasikan agar dapat berkomunikasi dengan efektif dan memberikan citra konsisten kepada pasar.

Komunikasi pemasaran terpadu menimbulkan paradigma baru dalam pemasaran. Perusahaan melakukan upaya mengintegrasikan komunikasi pemasaran mencakup: 1) memasang iklan (beriklan) di media massa (media advertising); 2) pemasaran secara langsung (direct marketing); 3) promosi penjualan (sales promotion); 4) penjualan secara personal (personal selling); 5) pemasaran interaktif; dan 6) hubungan masyarakat (public relations).

Komunikasi pemasaran terpadu (IMC) adalah proses pengembangan dan implementasi berbagai macam bentuk program komunikasi secara persuasif kepada pelanggan dan berkelanjutan (Shimp, Terence A. 2003). Tujuan IMC untuk mempengaruhi atau memberikan efek langsung pada perilaku sasaran. IMC menilai seluruh sumber dapat menghubungkan pelanggan atau calon pelanggan dengan produk potensial untuk menyampaikan pesan di masa datang. IMC juga menggunakan semua komunikasi yang relevan dapat diterima oleh pelanggan dan calon pelanggan. Proses IMC berawal dari pelanggan atau calon pelanggan, kemudian berbalik kepada perusahaan untuk menentukan dan mendefinisikan bentuk dan metode yang perlu dikembangkan bagi program komunikasi yang persusasif.

Four As (the American Association of Advertising Agency) sebuah Biro Iklan America, mendefinisikan IMC sebagai konsep perencanaan komunikasi pemasaran yang mengakui nilai tambah dari perencanaan komprehensif yang mengkaji peran bentuk strategis komunikasi misalnya iklan, respons langsung, promosi penjualan, dan (hubungan masyarakat) serta memadukannya meraih kejelasan pesan, konsistensi, dan 
dampak komunikasi maksimal melalui keterintegrasian pesan (Setia Hermawan, Agus, 2007).

Peneliti Don Schultz menilai definisi tersebut masih sempit atau bersifat terbatas tidak menggambarkan komunikasi pemasaran terpadu yang sebenarnya, Perspektif yang lebih luas perlu dipertimbangkan untuk seluruh sumber daya yang tersedia secara menyeluruh (Shimp, Terence A. 2003). Persepsi konsumen terhadap perusahaan dan/atau merek dagangnya adalah hasil integrasi dari berbagai pesan yang diterima seperti: iklan produk di media massa, harga produk, desain atau bentuk produk, publikasi, promosi penjualan, pemasaran langsung, websites, peragaan (display) produk dan bahkan bentuk toko atau outlet dimana produk itu dijual. Dengan demikian, perusahaan harus mengembangkan suatu strategi komunikasi pemasaran yang menyeluruh (Shimp, Terence A. 2003).

Komunikasi pemasaran terpadu (IMC) adalah mengintegrasikan perencanaan, tindakan dan koordinasi pada komunikasi pemasaran dan memahami konsumen termasuk tanggapan konsumen. Konsep IMC diperluas menjadi melalui empat jenjang: Merumuskan visi, misi, sasaran, dan tujuan untuk jadi pedoman perusahaan; Mempersatukan keterkaitan semua fungsi organisasi pemasaran; Menjaga integrasi fungsi dalam positioning, interaksi antara hubungan dan penerapan pemasaran berbasis misi, serta memperkuat jalinan hubungan untuk membina loyalitas dan memperkuat ekuitas merek.

\section{DATA PENELITIAN}

\section{Deskripsi Subyek Penelitian}

Digital marketing sebagai media sekaligus strategi komunikasi pemasaran produk Badan Usaha Milik Desa (BUMDesa) Pahlawan Ekonomi. Dari penelitian yang dilakukan, maka yang menjadi subyek penelitian adalah BUMDesa. Berikut adalah deskripsi subyek dalam penelitian:

1. Pak Sucipno, dipilih menjadi informan karena sebagai ketua BUMDesa dan sekaligus sebagai pengelola, Beliau umur 35 tahun (BUMDesa "Makmur Sejahtera", desa Sukosari Kidul, Kecamatan Sukosari, Kabupaten Bondowoso) :

2. Pak Yani dipilih menjadi informan karena sebagai ketua BUMDesa dan sekaligus 
sebagai pengelola, (Ketua BUMDesa Sumber Agung, Desa Alas Sumur, Kecamatan Pujer Kabupaten Bondowoso),

3. Pak Saleh M, MPd dipilih menjadi informan karena sebagai pengelola, dan sosok yang luar bisa bagi warga sekitarnya. Dengan gigih, beliau mendirikan usaha Kopi yang dipasarkan secara offline dan telah memanfaatkan digital marketing juga merupakan ketua BUMDesa Rejoagung Makmur Kecamatan Sumber Wringin Bondowoso,

4. Pak Agus (Ketua BUMDesa Bersama) Kecamatan Singosari Kab.Malang merupakan sosok yang peduli akan masyarakat bawah. Banyak sharing pengalaman terkait bagaimana pengelolaan BUMDesa atau lembaga pemberdayaan masyarakat yang berasal dari cikal bakal dari terbentuknya BUMDesa yaitu Unit Pengelola Keuangan (UPK) kecamatan.

5. Kepala desa serta sekdes Tanjung Tirto, BUMDesa Maju Bersama di desa Tunjung Tirto Kecamatan Singosari Kab Malang. berkolaborasi untuk membentuk usaha yang bermanfaat bagi warganya

\section{DESKRIPSI HASIL}

Setelah selesai pada tahapan pra lapangan dan pekerjaan lapangan, peneliti sampai pada tahap penyajian data penelitian. Pada bagian ini dipaparkan tentang deskripsi data penelitian, terutama yang terkait dengan data fokus penelitian yaitu mengenai strategi komunikasi pemasaran melalui digital marketing. Selain itu dipaparkan mengenai kendala dan manfaat ketika menerapkan digital marketing sebagai media komunikasi pemasaran terpadu pada produk BUMDesa.

Pengumpulan data-data penelitian terhitung sejak bulan Maret 2018 hingga awal Oktober 2018. Penggalian data selanjutnya diperoleh dari stakeholder dan informan yang dilakukan wawancara secara mendalam.

Peneliti pertama manemui Pak Sucipno, selaku ketua BUMDesa dan sekaligus inisiator pembentukan BUMDesa, Beliau umur 35 tahun (BUMDesa "Makmur Sejahtera", desa Sukosari Kidul, Kecamatan Sukosari, Kabupaten Bondowoso). 
Sekaligus untuk melanjutkan penggalian data sesuai instrument penelitian peneliti menggali informasi seputar komunikasi pemasaran terpadu dan penerapan digital marketing dalam usahanya.

Selanjutnya menemui Pak Yani sebagai ketua BUMDesa Sumber Agung, untuk menggali data mulainya terbentuknya BUMDesa hingga tercetus ide-ide terciptanya berbagai macam usaha yang dikelola BUMDesa. Lalu menemui Pak Saleh M, MPd sebagai tokoh dan sosok yang luar bisaa bagi warga sekitarnya. Karena kegigihan, beliau mendirikan usaha Kopi yang dipasarkan secara offline sampai memanfaatkan pemasaran digital.

Data terakhir dari hasil wawancara peneliti dilakukan dengan BUMDes di Kabupaten malang yang terdiri dari 2 BUMDesa, yaitu dengan Bapak Agus yang sangat peduli akan masyarakat kelas bawah. Dan Kepala desa serta sekdes dari desa Tunjung Tirto Kecamatan Singosari Kab Malang yang dengan kompak berkolaborasi untuk membentuk berbagai usaha yang bermanfaat bagi warganya.

Berdasarkan rumusan masalah yang diangkat oleh peneliti mengenai penerapan digital marketing sebagai strategi komunikasi pemasaran terpadu produk BUMDesa. Penggalian data sesuai instrument dengan penelitian untuk menggali informasi digital marketing dan komunikasi pemasaran terpadu. Agar terdeskripsikan secara baik maka peneliti mendeskripsikan data hasil penelitian, yakni sebagai berikut:

\section{STRATEGI KOMUNIKASI PEMASARAN MELALUI DIGITAL MARKETING YANG DILAKUKAN OLEH BUMDesa}

BUMDesa sebagai wadah untuk meningkatkan jiwa wirausaha dan kesejahteraan masyarakat desa untuk mewadahi pelaku usaha kreatif dalam mengembangkan bisnisnya. Untuk mengetahui penggalian data dari BUMDesa tersebut, peneliti sudah melakukan wawancara mendalam dengan Pak Sucipno, Pak Yani Pak Saleh M, MPd, Pak Agus dan Kepala desa serta sekdes desa Tunjung Tirto. Berikut data-datanya: 


\section{Perkembangan hingga menjadi BUMDesa .}

Pak Sucipno dari desa Sukosari Kidul, Kecamatan Sukosari, Kabupaten Bondowoso, kegiatan awal menjalankan usaha simpan pinjam, kemudian muncul program BUMDesa dari situlah awal dibangun, berikut ungkapannya : Program tersebut mengharuskan bentuk wirausaha berbasiskan kemampuan local dari desa. Awalnya BUMDesa makmur sejahtera berasal dari meneruskan kegiatan usaha ekonomi desa simpan pinjam (UED-SP) dan program lain yang diperuntukkan untuk desa dan itu bersifat pemberian dana bergulir berbunga sangat rendah untuk masyarakat miskin. BUMDesa dikelola oleh para pemuda desa termasuk plt sekretaris desa yang juga masih muda dan didukung oleh kepala desa. Pengelola BUMDesa dan perangkat desa berembuk untuk menjadikan potensi desa yang belum tergarap di TKD desa untuk dijadikan sebagai wahana obyek wisata desa. Berawal dengan bantuan teman yang merupakan pemerhati lingkungan dan suka membuat pertamanan sehingga muncul ide untuk membuat wisata desa yang sesuai dengan potensi alam di desa tersebut. Ide ini disambut baik oleh kepala desa dan disepakati menggunakan dana desa dan Tanah kas Desa (TKD). Kemudian para pemuda yang tergabung dalam Kelompok dasar wisata (kopdawis) desa menyulap tanah TKD yang awalnya tidak produktif karena posisi yang curam menjadi sebuah wahana wisata desa yang menarik untuk dikunjungi. Awalnya usaha BUMDesa ini adalah kolam ikan dan ada sumber mata airnya dijadikan sebagai wahana wisata yang dikemas dengan baik. Mulai Tahun 2017 digarap, bulan maret 2018 dibuka dan dipromosikan dengan melalui social media Facebook dan Instagran sehingga animo masyarakat untuk datang semakin tinggi. Rata-rata tiap bulan pendapatan BUMDesa dari hasil penjualan warung kulinernya mampu meningkat terus berkat banyaknya pengunjung yang ingin menikmati wisata desa yang dikelola BUMDesa Makmur Sejahtera, desa Sukosari Kidul, Kecamatan Sukosari, Kabupaten Bondowoso. Saat ini kampong wisata tirto agung menjadi spot baru bagi anak muda untuk sekedar selfi atau menikmati udara lereng gunung raung dan gunung ijen yang ada di sekitar desa sukosari kidul tersebut. Tidak salah kiranya pemerintah daerah mulai memberi perhatian lebih untuk desa tersebut menggeliat dengan BUMDesa-nya demi memberikan multiplier efek bagi kegiatan ekonomi masyarakat desa dan masyarakt lainnya. 
Pak Yani sebagai Ketua BUMDesa lainnya dari Desa Alas Sumur, Kecamatan Pujer Kabupaten Bondowoso, yang tidak kalah kreatifnya juga melakukan hal yang sama dalam memacu potensi desa untuk memberi tambahan aktifitas bagi warga sekitar desa, yaitu desa wisata rawa indah Almour. yang memiliki ide kreatif bersama karang taruna memberikan waktunya untuk menambah nilai lebih bagi bendungan kecil atau sejenis rawa dengan sumber air yang sangat deras untuk dijadikan sebagai wisata desa berbasis air dengan berbagai spot selfi yang sangat menarik untuk di viralkan melalui social media. Spot selfie memang dibuat khusus untuk mempromosikan melalui internet untuk menarik minat pengunjung untuk swa photo. Disekitarnya ditanami jambu berlin yang dibudidaya untuk menghijaukan sekitar kawasan wisata sekaligus memberi tambahan penghasilan dari petikan buah yang didapat.

Masih di Kabupaten Bondowoso merupakan wilayah yang dikelilingi oleh tiga gunung besar yaitu gunung raung, gunung ijen dan gunung argopuro. Wilayah sekitar pegunungan sangat subur dan baik untuk ditanami kopi rakyat. Wajar bila Kabupaten Bondowoso mempunyai tagline "Bondowoso Republik Kopi (BRK)" karena kawasan bondowoso kaya akan tanaman kopinya. Pak Saleh M, MPd, berada di salah satu kawasan desa yang penduduknya menanam kopi rakyat ada di desa Rejoagung Kecamatan Sumber Wringin. berawal dari petani di desa yang cukup terpencil dilereng gunung Ijen, tetapi beliau sosok yang luar bisaa bagi warga sekitarnya. Dengan kegigihan beliau merintis menanam tanaman kopi di lereng Gunung Ijen, beliau mendirikan usaha Kopi pertama kali dengan konsep tradisional dan dipasarkan hanya untuk daerah sekitarnya saja. Pak Saleh M, MPd yang merupakan ketua BUMDesa Rejoagung Makmur mampu melihat potensi desanya sudah didirikan sejak tahun 2016 untuk menggarap adanya kekayaan alam berkat tanaman kopi di desanya. Beliau menggarap potensi tersebut dengan mengembangkan tanaman kopi di desanya menjadi minuman yang berciri khas dengan aroma kopi Arabica dan berkualitas tinggi. Saat ini dengan semakin mudahnya internet mobile menggunakan Smartphone maka saat ini Usaha Kopi yang tergabung dalam BUMDesa sudah dipasarkan ke daerah lain dengan dipasarkan secara online dengan memanfaatkan digital marketing. Saat ini Produk kopi di tersebut telah diajukan untuk mendapat hak patent agar mampu menembus perdagangan luar negeri. Pengembangan Usaha pak Saleh dan perangkat desa serta 
pengelola BUMDesa lainnya telah dilakukan berbagai macam pelatihan khususnya tentang perkopian dari pasca panen sampai proses pengolahan kopi untuk dinikmati penikmat kopi dengan cita rasa tinggi sehingga bisa disandingkan dengan branded kopi yang sudah terkenal.

Pak Agus merupakan sosok yang dekat dengan masyarakat kelangan bawah, sehingga dengan adaya BUMDesa beliau ingin memaksimalkan potensi masyarakat sekitarnya untuk bergabung dengan BUMDesa. Melalui beliau banyak sharing pengalaman terkait bagaimana pengelolaan BUMDesa atau lembaga pemberdayaan masyarakat waktu itu yang sebenarnya cikal bakal dari terbentuknya BUMDesa yaitu Unit Pengelola Keuangan (UPK) kecamatan. BUMDesa bersama di kecamatan Singosari makin lebih baik dengan berbagai kerjasama yang telah dikembangkan oleh pak Agus dan pengelola BUMDesa lainnya untuk memulai bergerak dalam melakukan aktifitas ekonomi. Selain aktifitas di atas masih membantu BUMDesa yang baru terbentuk di desa se wilayah Kecamatan Singosari untuk tetap melakukan aktifitas ekonomi dengan kondisi sarana prasarana yang seadanya dimiliki, misalnya di BUMDesa Tamanharjo Makmur di desa Tamanharjo Kecamatan Singosari. BUMDesa tamanharjo makmur melakukan kerjasama usaha melalui unit usaha perdagangan dan jasa melalui media whatshap serta melakukan unit usaha lain yaitu penggemukan sapi yang akan dan telah digagas untuk dilakukan dengan banyaknya bahan pakan ternak melalui bahan pembuangan bahan pembuat pengrajin tempe. Hasil limbah pembuatan tempe dijadikan sebagai bahan pakan ternak unit usaha di BUMDesa tamanharjo makmur tersebut. Bagi desa yang tingkat ekonomi warganya lebih baik dan kepedulian dan kebersamaan untuk saling membantu dan saling mendorong memajukan desanya tentu akan berbeda hasil yang diperoleh.

Terakhir di BUMDesa Maju Bersama di desa Tunjung Tirto Kecamatan Singosari, dimana pengelola dan kepala desa serta sekdesnya berkolaborasi untuk membentuk berbagai manfaat bagi warganya. Salah satu BUUMDesa yang digarapnya dalah adanya took besar di tanah TKD dan akan dilanjutkan untuk membuat cafe untuk menunjang segala aktifitas ekonomi yang ada. Disosialisasikan melalui Instagram dan facebook untuk pemasarannya. Hasil yang diperoleh dari kegiatan tersebut bisa menjadikan BUMDesa di desa Tunjung Tirto tersebut sebagai wadah mensejahterakan warga desa 


\section{AKTIVITAS KOMUNIKASI PEMASARAN TERPADU PADA BUMDESA}

Aktivitas pemasaran merupakan penanda keberhasilan suatu perusahaan dalam usaha menjual serta meningkatkan nilai perusahaan di mata konsumen terhadap produk yang dihasilkan. Setelah memiliki produk unggulan dalam fokus bidang usaha yang digeluti, masing-masing BUMDesa mempunyai cara memasarkan produk-produk mereka, mulai dari cara memasarkan secara konvensional hingga pemasaran digital yang masih mereka praktikkan hingga sekarang.

Berikut penuturan dari semua BUMDesa, pada saat awal mendirikan usaha tersebut, mereka kebingungan untuk memasarkan produk maupun jasa wisata nya. Awal yang dilakukan semua BUMDesa adalah dengan cara offline dan word of mouth (WOM), seiring perubahan sikap masyarakat dalam penggunaan internet melalui smartphone, akhirnya semua BUMDesa melakukan upaya pemasaran dengan melalui online. Meskipun menggunakan media social yang sedikit berbeda antar BUMDesa yaitu dengan menggunakan aplikasi chatting WhatsApp, facebook dan instagram. Dengan cara menggunakan Facebook dan Instagram serta menerapkannya ke dalam usaha untuk memperluas jangkauan pasar. Para pengelola BUMDesa meyakinkan diri bahwa ini langkah yang memungkinkan untuk bekerja lebih efisien.

\section{STRATEGI PEMASARAN YANG DIJALANKAN OLEH BUMDesa DALAM MEMASARKAN PRODUK}

Strategi pemasaran yang tepat mampu menarik minat konsumen pada produk BUMDesa. Masing-masing BUMDesa memiliki strategi masing-masing, terutama mengenai konsistensi, perencanaan, dan strategi dalam membidik pelanggan untuk dapat menciptakan konsumen yang loyal terhadap produk yang disukainya. Berikut ini pernyataan masing-masing BUMDesa mengenai strategi pemasaran :

"Strategi pemasaran Pak Sucipno, menggunakan media sosial dan media online. Lewat postingan Facebook dan spot selfie instagram. Dan yang paling utama, strateginya dari orang-orang yang sudah datang ke sini yang dinamakan pemasaran langsung. Agar mendapat hasil lebih besar BUMDesa "Makmur Sejahtera" memang menargetkan para pengunjung lebih banyak. Yaitu dengan cara berinovasi dan me- 
rebranding tempat wisata dan wahana-nya. Bisa berupa inovasi permainan di dalam lokasi wisata.

"Strategi pemasaran Pak Yani, melalui media sosial dan media online. Postingan Facebook dan photo serta video instagram. Dengan tujuan menargetkan peningkatan para pengunjung dan dikenal luas oleh masyarakat. Dengan berinovasi tempat wisata menjadi lebih Instagramable (lebih indah untuk di photo). Juga memberikan harga tiket yang sangat murah utk sekali masuk dan bebas untuk semua wahana.

"Strategi pemasaran Pak Saleh M, MPd, menggunakan media offline dan online terutama melalui wharshap, Lewat postingan Facebook dan gambar2 produk di instagram. Agar mendapat hasil lebih besar BUMDesa memang menargetkan Yaitu dengan cara me-rebranding produk kopi ber Merk paten dan kemasan yang lebih baik, sehingga bisa bersaing dengan produk kopi yang lain. Saat ini produk kopi ini sudah mulai dikenal untuk seluruh kabupaten Bondowoso dan melalui media social mulai merambah luar negeri terutama Jepang.

"Strategi pemasaran Pak Agus, menggunakan media online whatshap. Strateginya utama dari pelanggan dengan konsep Loyalitas. Untuk mendapat hasil lebih besar dan pasar yang lebih luas BUMDesa bekerja sama dengan BUMDesa dari daerah lain yaitu Ngawi untuk produk pertanian yaitu padi. Usaha BUMDesa saat ini dikembangkan dengan kerjasama melalui program Raskin untuk penyaluran program BLT melalui whatshap.

"Strategi pemasaran Kepala desa serta sekdes desa Tunjung Tirto menggunakan media sosial dan media online. Lewat postingan Facebook untuk mengenalkan produk dan usaha BUMDesa, yang letak usaha mini market ini di lokasi yang sangat strategis berada di pinggir jalan raya utama menuju kota Batu. Rebranding yang dilakukan untuk menaikkan omset adalah dengan secara rutin melakukan postingan di Facebook untuk menampilkan informasi produk yang dijual dengan berbagai macam ragam photo dan informasi harga yang bersaing.

\section{Penerapan digital marketing yang dilakukan oleh BUMDesa}

Penerapan digital marketing pada media sosial ini telah memainkan peran penting dalam pengembangan bisnis. Hasil Wawancara dengan pengelola semua 
BUMDesa, sekarang produk dan tempat wisata yang dikelola oleh BUMDesa tidak hanya dikenal secara lokal daerah desa / kecamatan sekitar saja, tetapi sudah mulai dikenal oleh seluruh kabupaten Bondowoso dan Malang juga wilayah Jawa Timur.

Dengan media Facebook, Instagram dan whatshap ikut memberikan inspirasi bagi usaha lain di Indonesia, bahwa media digital bisa dimanfaatkan untuk berbisnis. Penerapan pengelola BUMDesa dalam memasarkan secara digital banyak dilakukan melalui posting photo dan video dari Facebook dan instagram. Konsisten dalam memasarkan produk melalui media sosial memang perlu ketelatenan, karena perlu waktu dan proses untuk membuat postingan photo dan video, hingga aktivitas bersosial media dan hasilnya juga tidak secara langsung. Dengan banyaknya fitur di sosial media sekarang akan semakin membantu dan memfasilitasi para pelaku usaha yang sudah memiliki akun bisnis untuk semakin mudah mengenalkan produk usaha milik mereka.

\section{KENDALA DAN MANFAAT PENERAPAN DIGITAL MARKETING BAGI BUMDESa DALAM MEMASARKAN PRODUKNYA}

Dari aktivitas pemasaran digital sangat memungkinkan terdapat pengaruh dari elemen pemasarannya, seperti dari sisi produk, harga, tempat, dan sistem pendistribusian. Masing-masing BUMdes mempunyai kendala yang berbeda-beda karena adanya perbedaan jenis produk atau jasa.

"Kendala pemasaran produk Pak Yani dan Pak Sucipno mempunyai kemiripan karena adanya persamaan produk tempat wisata, lokasi wisata yang sama memiliki jarak dari jalan utama yang cukup jauh dan dengan akses jalan yang masih kurang mendukung.

"Kendala pemasaran produk Pak Saleh M, MPd, Pak Agus dan Kepala desa serta sekdes desa Tanjung Tirto juga mempunyai kemiripan krn menjual produk pertanian dan pangan. Perbedaan hanya pada tingkat ketahanan masing produk yang berbeda, misal nya kopi dan kebutuhan bahan pokok seperti beras.

\section{RESULTS}

Tahapan analisis data merupakan tahap untuk mengolah serta menginterpretasikan data yang telah dikumpulkan sebelumnya, dan tahap ini peneliti 
menjabarkan data dari para informan dan menggabungkan konsep-konsep dari sumber kepustakaan. Proses interpretasi data dan analisis akan diperoleh hasil kesimpulan yang dinamakan temuan penelitian. Temuan ini menunjukkan hasil dari penelitian yang dilakukan. Pada penelitian ini peneliti memfokuskan pada BUMDesa yang menggunakan pemasaran digital (digital marketing) sebagai sebuah strategi komunikasi pemasaran terhadap target konsumennya. Adapun hasil dari penelitian ini, peneliti mendapatkan beberapa temuan yang dapat menggambarkan tentang Penerapan Digital Marketing sebagai Strategi Komunikasi Pemasaran Terpadu Produk Badan Usaha Milik Desa (BUMDesa) yakni sebagai berikut:

\section{Strategi Komunikasi Pemasaran Melalui Digital Marketing Yang Dilakukan Oleh Badan Usaha Milik Desa (Bumdesa) .}

Aktivitas pemasaran yang dilakukan para pengelola dan pengurus BUMDesa seperti yang diungkapkan para informan, selama ini memfokuskan pada tujuan untuk meningkatkan penjualan agar kesehjateraan meningkat. Untuk mencapai Tujuannya tersebut pemasaran produk BUMDesa lebih banyak dan luas dikarenakan pemasarannya sudah melalui digital. Di antaranya memiliki halaman group di Facebook yang bisa digunakan untuk saling mempromosikan produk-produk BUMDesa masing-masing. Facebook dan Instagram serta whatshap menjadi media pemasaran utama bagi BUMDesa, karenanya mampu meningkatkan omzet.

Poin penerapan pemasaran pada aplikasi media online facebook dan instagram serta whatshap yang dijalankan oleh BUMDesa antara lain:

1. Visualisasi Konten dikemas dengan menarik dan memiliki pesan persuasif. Memasarkan digital dilakukan melalui posting video dan photo di Facebook dan Instagram serta Whatsap. Konten yang bagus akan menarik banyak orang, meskipun saat awal pemasaran pemirsa Facebook maupun Instagram tidak memperhatikan produk yang dipromosikan tetapi jika dilakukan konsisten dan terus-menerus, mereka akan terpapar informasi mengenai produk tersebut.

2. Menanamkan kesadaran akan brand (brand awareness) produk BUMDesa tidak kalah dengan produk dan wisata di tempat yang sudah ternama.

3. Konsisten dalam memasarkan produk melalui media sosial memang perlu kesabaran, karena hasilnya tidak langsung saat itu juga. Harus rajin posting dan 
merespons chating dari para pemirsa atau follower dalam akun media sosial. Itu berguna untuk membangun kedekatan (engagement) dengan konsumen atau calon konsumen.

4. Membagikan informasi penting dan bermanfaat bagi pemirsa di akun media social dengan info memberikan promo, potongan harga, dan event khusus.

5. Menjalin hubungan dengan konsumen secara fast respond (cepat tanggap) terhadap tanggapan dan ulasan dari konsumen

6. Membangun brand awareness kepada konsumen dan calon konsumen itu penting, Cara menambahkan pemirsa pada akun sosial media, di Facebook maupun Instagram, harus cepat dan sering merespons pemirsa atau fast respond (cepat tanggap) ketika ada komentar pada postingan produk. Pemirsa atau pengikut di media sosial akan merasa diperhatikan melalui respon sekecil apapun itu.

7. Positioning statement dengan cara membangun branding.

8. Setelah penyampaian positioning statement telah diterima dan disimpan dalam benak pelanggan. Langkah selanjutnya membangun dan membina hubungan dengan pelanggan, yaitu merespon para pemirsa atau pengikut di akun media sosial dengan segera (fast respond) ketika mereka memberikan komentar atau memberi like pada postingan.

\section{Kendala Dan Manfaat Penerapan Digital Marketing Bagi Badan Usaha Milik Desa (Bumdesa)}

Kendala digital marketing bagi pengelola (BUMDESA) adalah

1. Kurang dari unsur komponen/variable dalam pelaksanaan pemasaran online, yaitu product, price, place, atau promotion-nya. Sehingga BUMDESA merasakan kendala ketika melakukan penjualan online.

2. Kendala BUMDESA berkaitan dengan pembayaran produk ketika terjadi pembelian online. Dikarenakan pembelian online merupakan pembelian tanpa bertatap muka langsung, maka pembayaran akan dialihkan dengan pembayaran transfer melalui ATM bank atau pembayaran lainnya. Kendala pembayaran metode transfer setelah transaksi pembelian adalah adanya jeda ketika selesai pemesanan dan pembayaran. Sering terjadi keterlambatan waktu menunggu konfirmasi informasi dari konsumen dan perbankan tentang pembeyaran transfer. Hal yang 
demikian itu memengaruhi lamanya proses waktu pendistribusian barang untuk sampai ke konsumen.

3. BUMDESA dengan model usaha desa wisata kendala yang paling dirasakan adalah tempat usaha yang sedikit kurang nyaman karena berada di lokasi yang jauh dari jalan raya kabupaten, akses jalan yang kecil dan jalan masih rusak. Hal semacam ini dapat mempengaruhi terutama transportasi dan menghambat waktu dalam perjalanan dan kenyamanan konsumen.

\section{TEMUAN TEORI}

Konfirmasi temuan dengan teori merupakan tahapan yang berguna untuk menentukan apakah teori tersebut masih relevan atau malah berbanding terbalik dengan penelitian yang ada. Temuan-temuan penelitian yang sudah dijelaskan sebelumnya akan dikonfirmasi dengan teori. Dan dalam penelitian ini peneliti menggunakan teori Integrated Marketing Communication (Komunikasi Pemasaran Terpadu). Adapun penjelasannya sebagai berikut:

1. Strategi komunikasi pemasaran melalui digital marketing yang dilakukan oleh BUMDESA adalah melalui penyampaian positioning statement pada setiap postingan di akun Facebook dan Instagram serta whatshap.

2. Penyampaian positioning statement di setiap postingan Facebook dan Instagram Menurut Don Schultz, penggunaan IMC mengharuskan terjadinya perubahan yang fundamental dalam cara-cara komunikasi pemasaran tradisional yang selama ini dilakukan seperti sebelumnya; memandang dan memisahkan elemen pemasaran (iklan, promosi, penjualan, hubungan masyarakat) yang seharusnya bisa diintegrasikan agar dapat menjalankan fungsi komunikasinya dengan efektif dan dapat memberikan citra yang konsisten kepada pasar. (Shimp, Terence A. 2003)

3. Komunikasi pemasaran terpadu menciptakan paradigma baru dalam pemasaran. Dan kini banyak perusahaan mulai menyadari perlunya upaya mengintegrasikan berbagai kegiatan komunikasi pemasaran yang selama ini dilakukan terpisah-pisah yang itu mencakup: 1) memasang iklan (beriklan) di media massa (media advertising); 2) pemasaran dilakukan secara langsung (direct marketing); 3) promosi penjualan (sales 
promotion); 4) penjualan secara personal (personal selling); 5) pemasaran interaktif; 6) hubungan masyarakat (public relations).

4. Komunikasi pemasaran terpadu mempromosikan produk melalui media elektronik atau internet termasuk bentuk pemasaran interaktif. Internet telah merubah cara perusahaan merancang dan melakukan strategi bisnis dan pemasaran. Tradisional komunikasi pemasaran seperti iklan sifatnya hanya satu arah, sebaliknya media interaktif memudahkan pengguna melakukan berbagai fungsi seperti menerima dan mengubah informasi dan gambar, mengajukan pertanyaan, menjawab pertanyaan dan tentu saja melakukan pembelian.

5. Teori komunikasi pemasaran terpadu (Integrated Marketing Communicatio) terdapat konsep IMC yakni Relationship Marketing, Para pelaku pemasaran berorientasi pasar harus memfokuskan upaya untuk mempertahankan hubungan dengan pelanggan, tidak hanya terjadinya sekali pertukaran atau sekali transaksi pelanggan. Para pelaku pemasaran memberikan perhatian mendorong pada apa yang disebut dengan relationship (Setia Hermawan, Agus. 2007).

6. Marketing, Peranan hubungan masyarakat seperti perlu personal branding dari pelaku usaha atau pemasar, yaitu dengan respon atau menanggapi dengan cepat dari pertanyaan dan tanggapan yang dilontarkan oleh pelanggan melalui media sosial. Sehingga pelanggan mendapat layanan yang cepat atau jawaban terbaik dari pemasar.

\section{KESIMPULAN}

Berdasarkan hasil temuan data dan konfirmasi teori penjelasan tentang rumusan masalah yang peniliti lakukan, maka dapat diambil beberapa kesimpulan antara lain:

1) Strategi komunikasi pemasaran melalui digital marketing yang dilakukan oleh pelaku usaha BUMDESA yaitu penyampaian positioning statement di setiap postingan Facebook dan Instagram serta menjalin hubungan dengan pelanggan secara fast respond (cepat tanggap) di media sosial. Strategi tersebut dapat membangun dan mempengaruhi kesadaran merek pada konsumen atau calon konsumen sehingga mereka familiar dengan eksistensi merek (brand). 
2) Kendala dan manfaat digital marketing bagi pelaku usaha BUMDESA. Dari sisi kendala pengaruhnya langsung pada komponen pemasaran yaitu letak yang jauh dan sulit karena kurang strategis; pembayaran transfer terkadang sedikit lambat dari pembayaran tunai melalui tatap muka langsung. Sedangkan manfaat digital marketing adalah semakin dikenalnya produk BUMDESA.

3) Dengan produktivitas BUMDes meningkat. Maka akan meningkatkan dampak positif bagi masyarakat di sekitarnya.

\section{DAFTAR PUSTAKA}

Alkadafi, Muammar, 2014, Penguatan Ekonomi Masyarakat Melalui Pengelolaan Kelembagaan Badan Usaha Milik Desa Menuju ASEAN Economic Community 2015, Fakultas Ekonomi Dan Ilmu Sosial Universitas Islam Negeri Sultan Syarif Kasim, Riau.

Andreas Kaplan and Michael Haenlein, 2010, "Users of The World, Unite! The Challenges and Opportunities of Social Media". Kelley School of Business, Business Horizon, Vol. 53, No. 1.

Bambang Dwi Atmoko, 2012, Instagram Handbook, Jakarta: Media Kita

Bank Indonesia, "Undang-Undang No. 20 tahun 2008" dalam http://bi.go.id/uu- bi/documentsIB

Bratha, I Nyoman. 1968, Penuntun Geografi Sosial, UP Spring, Yogyakarta.

Chafey, Dave et al. 2000 Internet Marketing: Strategy, Implementation, and Practic. England: Pearson Education Limited

Dan Zarella, 2010, The Social Media Marketing Book. Canada: O'Reilly Media

Daniel Iman K dkk, 2005, "Pengaruh Pemasaran Melalui Media Sosial terhadap Kesadaran Konsumen pada , Internasional", Jurnal Administrasi Bisnis Universitas Brawijaya Malang, Vol.24 No. 1 Juli

Dave Chaffey. 2015, Digital Business and E-Commerce Management, Strategy, Implementation, and Practice. England: Pearson Education Limited

Dedi Purwana ES, dkk, 2017 , "Pemanfaatan Digital Marketing Bagi Usaha Mikro, Kecil, dan Menengah (UMKM) di Kelurahan Malaka Sari, Duren Sawit”. Jurnal Pemberdayaan Masyarakat Madani . Vol. 1 No. 1, Juli 
Departemen Pendidikan Nasional Pusat Kajian Dinamika Sistem Pembangunan (PKDSP), 2007. Buku Panduan Pendirian Dan Pengelolaan Badan Usaha Milik Desa (Bumdes), Fakultas Ekonomi Universitas Brawijaya, Malang.

E. Kristi Poerwandari. 2005, Pendekatan Kualitatif untuk Perilaku Manusia, Jakarta: Mugi Eka Lestari

Kobis Zarella,Dan, 2010, The Social Media Marketing Book. Canada: O'Reilly Media

Kotler ,Philip dan Kevin Lane Keller. 2007.Manajemen Pemasaran Jilid 2. Jakarta: Indeks

Kotler,Philip \& Gary Amstrong, 1997. Prinsip-prinsip Pemasaran, Jilid 1, Jakarta: Erlangga

Lexy J. Moleong, 2009, Metodologi Penelitian Kualitatif, Bandung: Remaja Rosdakarya

Monica Utari, 2011, "Pengaruh Media Sosial Instagram Akun@Princessyahrini Terhadap Gaya Hidup Hedonis Para Followersnya". Jurnal Ilmu Komunikasi FISIP, Vol.4

Morissan. 2015.Periklanan: Komunikasi Pemasaran Terpadu. Jakarta: Kencana Prenada Media

N. Berkowitz, Eric dkk. 2000.Marketing 6th Edition. New York: Irwin/McGrawhill

Peter Salim dan Yenny Salim, 2002, Kamus Bahasa Indonesia Kontemporer, Modern English Perss, Jakarta,

PP No. 72 Tahun 2005 tentang Desa.

Rafi Mohammed. 2003, Internet Marketing: Building Advantage in a Networked Economy. USA: McGraw-Hill

Setia Hermawan, Agus. 2007. Komunikasi Pemasaran. Jakarta: Penerbit Erlangga

Shimp, Terence A. 2003.Periklanan Promosi Aspek Tambahan Komunikasi Pemasaran Terpadu Jilid 1. Jakarta: Erlangga

Slyvia M Chan-Olmsted., Monhee Cho, and Sangwon Lee. 2013. User Perception of Social Media: A Comparative study of Perceived Characteristics and User Profiles by Social Media. Online Journal of Communication and Media Technologies. Vol. 3, No. 4

Strauss, and Corbin J. 1998. Basics of Qualitative Research: Grounded Theory Procedure and Technique, 2nd edition. Newburry Park, CA: Sage Publications 
Sudarwan Danim. 2002, Menjadi Peneliti Kualitatif. Bandung: Pustaka Setia

Sugiyono. 2011 Metode Penelitian Kuantitatif, Kualitatif, dan R \& D. Bandung: Alfabeta

Tjiptono ,Fandy. 2008 Strategi Pemasaran Edisi III. Yogyakarta: Penerbit Andi Muhammad,

UU No. 32 tahun 2004 tentang Pemerintahan Daerah

Zainal Muttaqin, 2011, "Facebook Marketing Sebagai Komunikasi Pemasaran Modern", Jurnal Sistem Informasi, Vol. 1 No. 2, Juli

https://www.whatsapp.com/business?ref=fbb_ens,

http://blog.sociomile.com

https://business.facebook.com/business/products/ads\#

https://business.facebook.com/business/products/ads\#

https://business.instagram.com/advertising?locale=id_ID

https://business.instagram.com/blog/creating-a-business-profile-on- instagram/

https://business.instagram.com/blog/creating-a-business-profile-on-instagram/

https://business.instagram.com/getting-started/\#get-a-business-profile

https://digitalmarketer.id/social-media/updatean-terbaru-social-media-instagrammeluncurkan-instagram-stories/

https://websindo.com/indonesia-digital-2019-media-sosial/

https://www.cnnindonesia.com/teknologi/

https://www.cnnindonesia.com/teknologi/ 